\title{
The regulation of immune cells by Lactobacilli: a potential therapeutic target for anti-atherosclerosis therapy
}

\author{
Ya-Hui Ding ${ }^{1,2}$, Lin-Yan Qian ${ }^{1,2}$, Jie Pang ${ }^{1,2}$, Jing-Yang Lin ${ }^{1,2}$, Qiang $X \mathbf{u}^{1,2}$, Li-Hong \\ Wang $^{1,2}$, Dong-Sheng Huang ${ }^{2,3}$ and Hai Zou ${ }^{1,2}$ \\ ${ }^{1}$ Department of Cardiology, Zhejiang Provincial People's Hospital, Hangzhou 310014, China \\ ${ }^{2}$ People's Hospital of Hangzhou Medical College, Hangzhou 310014, China \\ ${ }^{3}$ Department of Hepatobiliary Surgery, Zhejiang Provincial People's Hospital, Hangzhou 310000, China \\ Correspondence to: Jing-Yang Lin, email: ljy@zjheart.com \\ Qiang Xu, email: xuqiang@zjheart.com \\ Li-Hong Wang, email: wanglh@zjheart.com \\ Dong-Sheng Huang, email: dshuang@zju.edu.cn \\ Hai Zou, email: haire1993@163.com
}

Keywords: atherosclerosis, Lactobacillus, lymphocyte, macrophage, dendritic cell

Received: February 17, 2017 Accepted: May 22, $2017 \quad$ Published: June 02, 2017

Copyright: Ding et al. This is an open-access article distributed under the terms of the Creative Commons Attribution License 3.0 (CC BY 3.0), which permits unrestricted use, distribution, and reproduction in any medium, provided the original author and source are credited.

\section{ABSTRACT}

Atherosclerosis is an inflammatory disease regulated by several immune cells including lymphocytes, macrophages and dendritic cells. Gut probiotic bacteria like Lactobacilli have been shown immunomodificatory effects in the progression of atherogenesis. Some Lactobacillus stains can upregulate the activity of regulatory T-lymphocytes, suppress T-lymphocyte helper (Th) cells Th1, Th17, alter the Th1/Th2 ratio, influence the subsets ratio of M1/M2 macrophages, inhibit foam cell formation by suppressing macrophage phagocytosis of oxidized low-density lipoprotein, block the activation of the immune system with dendritic cells, which are expected to suppress the atherosclerosis-related inflammation. However, various strains can have various effects on inflammation. Some other Lactobacillus strains were found have potential pro-atherogenic effect through promote Th1 cell activity, increase proinflammatory cytokines levels as well as decrease anti-inflammatory cytokines levels. Thus, identifying the appropriate strains is essential to the therapeutic potential of Lactobacilli as an anti-atherosclerotic therapy.

\section{INTRODUCTION}

Atherosclerosis (AS) is one of the most common chronic non-infectious diseases worldwide. AS is associated with several serious cerebrovascular diseases such as acute coronary syndrome, and stroke. AS was originally thought to result from accumulation of toxic lipids due to dysfunctional lipid metabolism. In recent years, however, mounting evidence suggests that inflammation, which involves innate and adaptive immune responses, may play a critical role in the development and progression of AS. For example, large concentrations of immune cells, such as macrophages, dendritic cells (DCs), and lymphocytes, have been identified in AS plaques.
These cells secrete chemokines and pro-inflammatory, anti-inflammatory factors and adhesion factors, which contribute to AS pathogenesis [1].

This revelation suggests that anti-inflammatory therapeutics may inhibit or reverse the progression of AS. In a recent study, it was determined that treatment with anti-inflammatory pharmaceuticals statins reduced incidents of stroke in a rat model of AS [2]. Inhibitors of renin-angiotensin system (RAS), calcium channel blockers, aspirin and some other medicines also exhibited anti-atherogenetic effects by reducing inflammation.

A recent anti-inflammatory agent of interest is probiotic bacteria Lactobacilli. This probiotic is essential to several bodily processes including fermentation and 
decomposition of indigestible substances, stimulation of cell growth, regulation of the immune system, and destruction of pathogenic bacteria. Several recent studies have revealed a potential therapeutic role for probiotic bacteria against AS. Recent studies found that some Lactobacillus strains significantly reduce the arteriosclerotic index [3-5]. These effects are largely due to the immunomodulatory functions of Lactobacilli. Remarkably, the difference of immune modification effects in various strains of Lactobacilli leads to distinguished features in pathogenesis of atherosclerosis. Some strains of Lactobacilli promote the inflammatory response of immune cells which may augment atherogenesis [6-9]. In this review, we will provide an overview of the effects concerning AS, especially the potential anti-atherogenetic effects, of Lactobacilli mediated through immune cells.

\section{Overview of immune cells in the development and progression of $\mathrm{AS}$}

AS involves the complicated interaction between several immune cells and cytokines, its triggering factors include lipoprotein, reactive oxygen species, hypertension, shear force, smoking, etc. Endothelial dysfunction induces the initiation of atherogenesis which characterized by chemotaxis and adhesion of monocytes and T-lymphocytes to the endothelial surface via chemotactic factor like MCP-1 and adhesion molecules like VCAM-1. Then, various immune cells involve in the progression of atherogenesis (Figure 1).

\section{Monocytes and macrophages}

Macrophages are important immune cells in both innate and adaptive immune responses. They are also an important source of inflammatory factors. Macrophages play a critical role in the development of AS. During AS progression, the macrophages aggregate to form "foam cells" which increase the rupture risk of AS plaques $[10,11]$.

The monocytes migrate into the arterial intima and, in response to chemokines and related receptors, convert into macrophages driven by cytokines like macrophage colony-stimulating factor (M-CSF), and express Tolllike receptor (TLR), pattern recognize receptor (PRR) and scavenger receptor $[12,13]$. Macrophages take up low-density lipoprotein (ox-LDL) through scavenger receptor $\mathrm{B}$, and in response release pro-inflammatory cytokines which promotes a focal arterial endothelial immune response and accelerates the formation and development of AS [14]. Myeloid monocytes differentiate into pro-inflammatory (M1) and anti-inflammatory (M2) macrophages after migrating into tissues. M1 macrophages kill microbes and produce pro-inflammatory cytokines, such as tumor necrosis factor $\alpha$ (TNF- $\alpha$ ), interleukin 6 (IL-6), IL-12 and MCP-1, as well as secrete extracellular matrix proteins, MMP-2 and MMP-9, all of which exacerbate AS. M2 macrophages produce anti- inflammatory cytokines, such as IL-10, TGF- $\beta$, IL-1Ra and AMAC-1 (CCL-18) while also removing cell fragments, promoting angiogenesis and improving tissue remodeling and repair [15]. Differentiated M1 and M2 macrophages can be converted to one another [16]. M2 macrophages convert to M1 macrophages during plaque progression while M1 macrophages convert to M2 macrophages during plaque regression [17]. Thus, the polarization of macrophages may serve as biomarkers of the pathologic progression of AS in principle.

\section{T-lymphocytes}

T-lymphocytes play a key role in the development and progression of AS. Following the formation of AS plaques, T-lymphocytes cluster along the periphery, fibrous cap and in the center of the plaques. As the disease progresses, the number of bordering T-lymphocytes gradually increases. The T-lymphocytes are activated by various endogenous and exogenous stimulators, such as ox-LDL. The activated T-lymphocytes then secrete cytokines like granulocyte-macrophage colony stimulating factor (GM-CSF), interferon $\gamma$ (IFN- $\gamma$ ), TNF- $\beta$, IL-2, IL-4 and IL-6, which promote the development of AS [1]. T-lymphocytes can be classified into subsets according to their immunophenotype. These subsets include helper $\mathrm{T}$ (Th) cells and regulatory $\mathrm{T}$ (Treg) cells. Th1 cells promote inflammatory responses by secreting pro-inflammatory cytokines, like IFN- $\gamma$, TNF- $\alpha$ and TNF- $\beta$ [18]. In AS plaques Th1 cells produce IFN- $\gamma$ and activate macrophages [19]. Th2 cells can inhibit macrophages phagocytize oxLDL mediated by scavenger receptor. Deletion of IL-5 and IL-13, two Th2 cytokines, accelerates AS [20, 21], while deficiency of IL-4, another Th2 cytokines may attenuate the development of AS [22]. So the anti-atherogenetic effects of Th2 cells are still unclear and controversial [23]. Th17 cells mainly secrete inflammatory cytokine like IL-17 and IL-2. A proatherogenic role of IL-17 is found in some studies, but the results are controversial [24]. IL-17 blockade led to reduce AS in Apoe-/- mice in some studies $[25,26]$, while in other study, IL-17 did not affect plaque burden even it contributes to vascular and systemic inflammation [27]. Furthermore, the increased number of Th17 cells or Th17/Treg ratio were found in some clinical research $[28,29]$. It suggests that Th17 cells have a detrimental impact on atherosclerotic plaque stability. Treg cells inhibit the immune response of DC, Th1, Th2 and Th17, and increase the expression of TGF- $\beta$, IL-10, and IL-5, which may inhibit the proliferation of bystander $\mathrm{T}$ cells in an IL-10-dependent fashion [30, 31].

\section{Nature killer cells}

Nature killer (NK) cells, innate lymphocytes capable of lysing target cells, have an immunoregulatory effects in the pathogensis and development of AS. MCP-1 


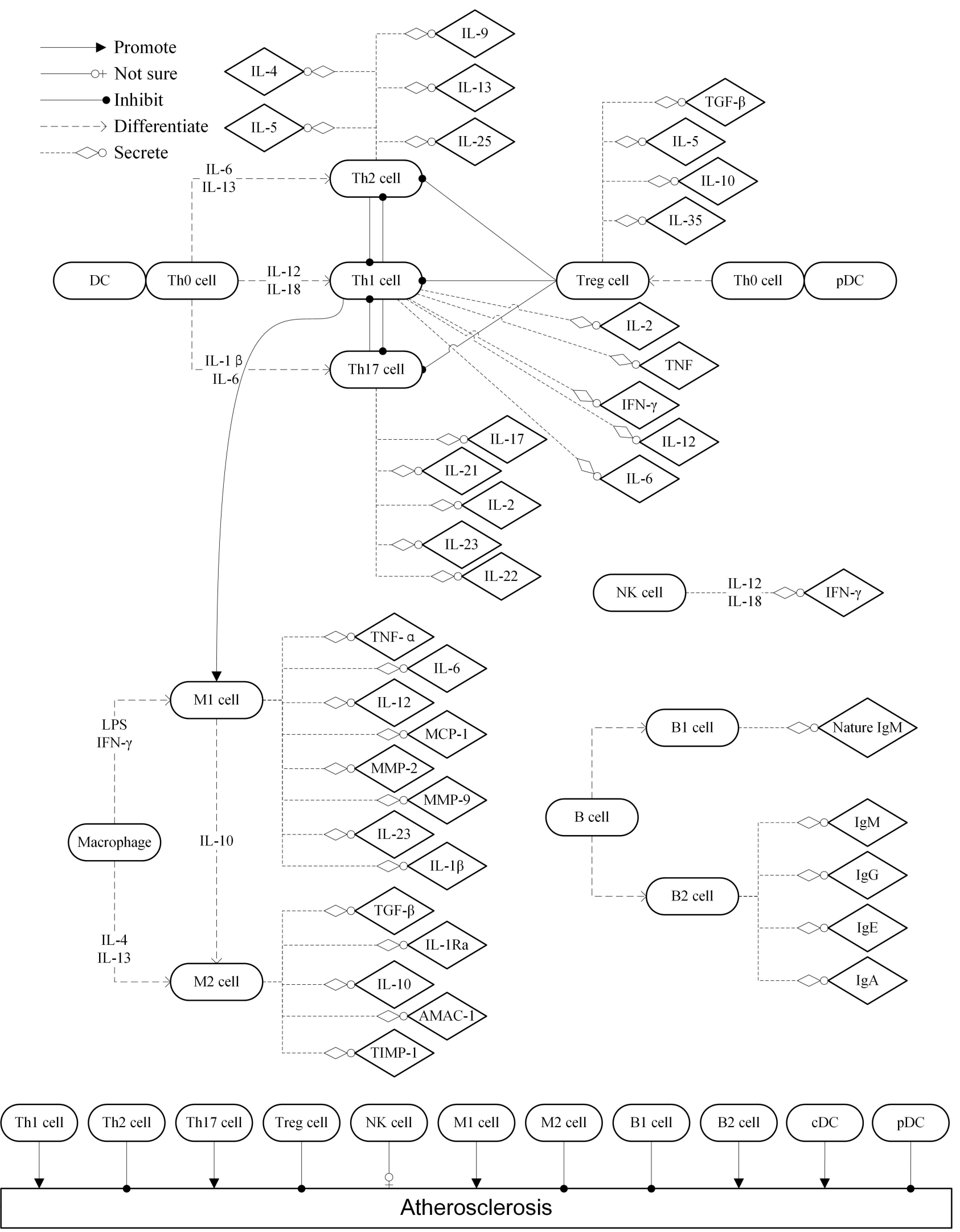

Figure 1: The role of immune cells in the progression of atherogenesis. DC: dendritic cell; IL: interleukin; TNF: tumor necrosis factor; IFN: interferon; TGF: transforming growth factor; Treg: regulatory T; Th: T-lymphocyte helper; pDC: plasmacytoid DC; cDC: classic DC; MCP: monocyte chemotactic protein; AMAC: alternative macrophage activation-associated CC chemokine; TIMP: tissue inhibitor of metalloproteinase; NK: nature killer; MMP: metal matrix proteinase. 
recruits NK cells in the AS lesions, and CX3CL1 induce NK cell migration and activation which cause increased cytotoxicity and pro-atherogenic cytokine IFN- $\gamma[32,33]$. Increased circulating NK cell levels were found in some studies [34, 35], however, reduced NK cell levels were observed in other studies [36-38]. A study in LDLR-/beige mice suggested that atheroprotective effect of $\mathrm{NK}$ cells was independent of its cytotoxicity but cytokine production might be the major factor [39]. Therefore, it is still unclear whether NK cells are pro-atherogenesis or anti-atherogenesis, related to their cytolytic activity or cytokine secretion.

\section{B-lymphocyte}

B-lymphocytes, derived from bone marrow, are vital to adaptive immunity in that they by produce immunoglobulin that participate in humoral immunity. According to recent studies, the immune-protective effect of B-lymphocytes may also contribute to AS development $[40,41]$. However, the lack of B-lymphocytes promotes the formation and development of coronary atherosclerosis heart diseases in human [42]. Further research revealed the different anti-atherogenetic effects of various B-lymphocytes subsets. B1 cells prevent lesion formation, whereas B2 cells promote it [43]. B1 cells secrete poorly specific nature IgM antibodies and attenuate atherosclerotic burden, which may link with preventing oxLDL internalization by macrophages and apoptotic cell accumulation by enhanced efferocytosis $[43,44]$. B2 cells secrete all human immunoglobulin classes, namely $\operatorname{IgM}, \operatorname{IgG}, \operatorname{IgE}$ and $\operatorname{Ig} \mathrm{A}$, and appear to augment atherogenesis through antibody dependent or independent mechanisms $[45,46]$.

\section{Dendritic cells}

Dendritic cells (DCs) are the most powerful professional antigen-presenting cells (APC). DCs are subdivided into plasmacytoid DCs (pDCs) and classic DCs (cDCs) depending on their phenotype and functions. DCs take in and process antigens effectively, then present antigens to memory T-lymphocytes to activate an immune response. DCs can secrete several cytokines, mainly IL-12, IL-10, IL-23, IL-6, IL-1 $\beta$, TNF- $\alpha$, TGF- $\beta$, as well as express various maturation markers, such as CD40, CD54, CD80, CD83, CD86 and MHC complex [47, 48]. Activated DCs in the vascular endothelium highly expressed adhesion markers like ICAM-1, and VCAM-1 which activate T-lymphocytes [2]. Lord et al. found that DC-mediated immune responses were found to be involved in the early stage of atherogenesis, evidenced by the fact that DCs increased significantly in the atheroprone areas of normal arterial wall [49-52].Moreover, high expression of DC's costimulate molecule CD86 is associated with stable coronary artery disease as well as acute coronary syndrome [53]. Some DC subsets, such as Intestinal CD103+ DCs, are also the key for tolerogenic immune responses, they can promote the differentiation of Treg cells [54, 55]. Manikandan et al. found that MyD88 signaling in CD11C+ DCs play a key role during the T-lymphocytes activation in atherogenesis because it promote the development of atheroprotective Treg cells [56]. Furthermore, Isabelle et al. found that pDCs demonstrated a protective role in AS [57]. It may be caused by inhibiting $\mathrm{T}$ cell proliferation and activity in peripheral lymphoid tissue. Thus suppressing DC maturity and antigen-present function is regarded as one of the antiatherogenetic mechanisms of statins [2].

\section{Inflammatory response of Lactobacilli in lymphocytes}

\section{T-lymphocyte}

Several studies now show that Lactobacilli reduces inflammatory response via T-lymphocytes. Particularly, Treg cells play a vital role in the inhibitory effect of Lactobacilli on inflammation. There are positive correlations between the number of Treg cells and Lactobacilli [30, 58-62]. Treg cells increase IL-10 level and inhibit the proliferation of bystander T cells in an IL10-dependent fashion [30]. Lactobacilli are also effective in inducing CD4+CD25+Foxp3+ Treg cell mediated tolerance [63].

In Kim et al. study, treatment with Lactobacillus rhamnosus Lcr35 was found to increase the number of CD4+CD25+Foxp3+ Treg cells in the spleens and mesenteric lymph nodes of mice $[59,60,64]$. Lcr35 also suppressed Th1 (IFN- $\gamma$ ), Th2 (IL-4, IL-5, and IL-13) and Th17 (IL-17) cell cytokines in the serum, and thymic stromal lymphopoietin (TSLP) responses. The protective effects of Lcr35 was blocked by anti-CD25 mouse antibody, which indicated that CD4+CD25+Foxp3+ Treg cells are indispensable in mediating the activity of Lcr35. Similar effects, (ie upregulation of CD4+CD25+Foxp3+ Treg cells) was observed with other Lactobacillus strains, such as Lactobacillus rhamnosus GG [65], Lactobacillus casei ATCC 334 [66], Lactobacillus reuteri ATCC 23272 [58], and Lactobacillus paracasei L9 [63]. Furthermore, Reynolds et al. found that Lactobacillus taiwanesis elevated Treg cells in the gut-associated lymphoid tissue without raising Th17 cell responsiveness [62].

However, it is important to note that different strains may have different immunomodulatory effects on Th1 and Th2 cells. A study in healthy wild-type male $\mathrm{BALB} / \mathrm{c}$ mice showed that, in the small intestinal lamina propria, Lactobacillus plantarum WCFS1 significantly decreased the Th1/Th2 cell ratio. However, Lactobacillus salivarius UCC118 and Lactobacillus lactis MG1363 had no effect [67]. Lactobacillus rhamnosus LA68, on the other hand, activated the Th1 immune response in healthy C57BL/6 mice [6]. Studies on hypersensitive 
ovalbumin (OVA)-sensitized mice/rats revealed that Lactobacillus strains induced Th1 cytokines and inhibit Th2 cell cytokines, which improved immune balance and relieved the hypersensitivity [7-9]. Similar changes to the Th1/Th2 cell ratio were observed in influenza A/NWS/33 (H1N1) virus (IFV) infected BALB/c mice that were administrated by Lactobacillus fermentum CJL-112 [68]. Moreover, in the same mouse model, Lactobacillus casei Shirota attenuated the Th2 cell phenotype. In contrast, Lactobacillus plantarum WCFS1 augmented the Th2 cell phenotype [69]. Taken together, these studies demonstrate that the variant between Lactobacillus strains plays a critical role in immune response variation (Table 1).

Generally, Lactobacilli can be roughly classified as pro-inflammatory strains and anti-inflammatory strains according to their influence on T-lymphocyte subsets. But the effects of some T-lymphocyte subsets like Th2 and Th17 are still controversial as well as the complex interaction between T-lymphocyte subsets, it is difficult to explicate the anti-atherogenetic effects of Lactobacilli via T-lymphocytes path exactly. Nevertheless, current research revealed that Treg cells are a key component in inhibiting AS-related inflammation. Certainly, the exact roles of T-lymphocytes in the formation and development of AS are still need to be elucidated.

\section{B-lymphocyte}

The Lee et al. study showed Lactobacillus plantarum could stimulate murine splenocyte proliferation, and this effect in dead nano-sized Lactobacillus plantarum was more apparent than in pure live bacteria [7]. Lactobacillus helveticus SBT2171 was found to inhibit the proliferation of T-lymphocytes and B-lymphocytes in LPS-stimulated mice [70]. While, Lactobacillus plantarum CJNR26 and Lactobacillus gasseri CJMF3 increased the B-lymphocyte population in the spleen of mice [71]. A dose-response, double-blind, placebo-controlled, randomized pilot trial showed that low dose Lactobacillus plantarum CECT 7315 and CECT 7316 increased activated B-lymphocytes (CD19+) as well as T-helper lymphocytes (CD4+CD25+) [72]. But unfortunately, until recently, there was no direct evidence demonstrating the antiatherogenetic effect of Lactobacilli via B-lymphocytes. Therefore, it is unclear what role Lactobacilli are playing in the atherogenesis and development of AS via B-lymphocyte pathway.

\section{Nature killer cells}

Some studies showed that Lactobacilli can augment NK cell activity, like Lactobacillus plantarum 06CC2 [73], Lactobacillus delbrueckii OLL1073R-1 [74], Lactobacillus casei Shirota [75], Lactobacillus casei HY7213 [76]. Lee et al. found that Lactobacillus plantarum HY7712 protected against the impairment of NK cell activity caused by $\gamma$-irradiation or aging through activating the TLR2/NF- $\kappa \mathrm{B}$ signaling pathway (24105270). In fact, Lactobacilli can activate NK cells as well as induce augmentation of immune responses of Th1 cells, cytotoxic $\mathrm{T}$ cells, macrophages $[73,76]$, increase the production of IFN- $\gamma$, IL-12 $[74,77,78]$ at the same time. However, Dong et al. found Lactobacillus casei Shirota improved NK cell activity as well as increase IL10/IL-12 ratio in older population [79]. Another study involved six probiotic strains (Lactobacillus casei Shirota, Lactobacillus rhamnosus GG, Lactobacillus plantarum NCIMB 8826 and Lactobacillus reuteri NCIMB 11951, Bifidobacterium longum SP 07/3 and B. bifidum MF 20/5) showed increasing NK cell activity, but some cytokines levels, like IL-10, IFN- $\gamma$, IL-12p70, IL-6 and MCP-1, were strain-specific [80].

The truth is, there are still much controversy to the effects of NK cells in atherogenesis, so it is still unknown about NK cell activation by Lactobacilli for atherogenesis and development of AS unless there is some direct evidence.

\section{Inflammatory response of Lactobacilli in macrophage}

A study found administration of Lactobacillus gasseri SBT2055 decreased the number of macrophages and the M1/M2 ratio in mice [81]. The similar effects could be observed in Lactobacillus paracasei [82], Lactobacillus plantarum CLP-0611 [83], and Lactobacillus brevis G-101 [84]. Furthermore, some Lactobacillus strains, such as Lactobacillus plantarum OLL2712 [85], Lactobacillus rhamnosus ATCC 7469 [86], Lactobacillus rhamnosus GG MTCC 1408 [87] and Lactobacillus helveticus NS8 [88] were revealed to increase the production level of IL-10 which is regarded as an important anti-inflammatory cytokine that inhibits atherogenesis.

On the other hand, some Lactobacillus strains were found to increase the pro-inflammatory production levels of macrophages, like TNF- $\alpha$ and IL-6 [86, 89, 90]. However, decreased TNF- $\alpha$ and IL- 6 production levels of macrophages were observed after treatment with other Lactobacillus strains [81, 87, 91]. Taken together, these results indicate that the pro-inflammatory and anti-inflammatory effects of Lactobacilli have notable differences in various strains and experimental models.

In fact, Lactobacilli have influenced cholesterol metabolism in macrophages. Lactobacillus paracasei regulate alveolar macrophages cholesterol metabolism and the response to LPS in Ossabaw pigs. It decreased the concentrations of cholesteryl-esters and suppressed expression of pro-inflammatory mediators in alveolar macrophages [92]. In some clinical trials, such effects are also found, but the results are somewhat ambiguous. A controlled, randomized, double-blind trial discovered administration of Lactobacillus plantarum mixture of 
Table 1: Inflammatory response of Lactobacilli in T-lymphocytes

\begin{tabular}{|c|c|c|c|c|c|c|}
\hline Strains & Th1 & Th2 & Th17 & Treg & Inflammatory cytokines & Reference \\
\hline Lactobacillus rhamnosus Lcr35 & $\downarrow$ & $\downarrow$ & $\downarrow$ & $\uparrow$ & 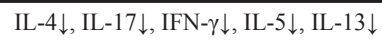 & Jang et al. $[59,60,64]$ \\
\hline Lactobacillus rhamnosus GG & & & & $\uparrow$ & 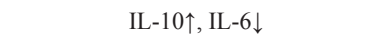 & Khailova [65] \\
\hline Lactobacillus casei ATCC 334 & & & & $\uparrow$ & IL-10^ & Tiittanen [66] \\
\hline Lactobacillus reuteri ATCC 23272 & & & & $\uparrow$ & IL-10个, MCP-1/CCL $2 \downarrow$, TNF $\downarrow$, IL-5 $\downarrow$ & Karimi [58] \\
\hline Lactobacillus paracasei L9 & & & & $\uparrow$ & 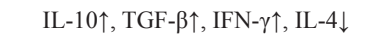 & Yang [63] \\
\hline Lactobacillus taiwanesis & & & & $\uparrow$ & & Reynolds [62] \\
\hline Lactobacillus plantarum WCFS1 & $\downarrow$ & $\uparrow$ & & & $\mathrm{IL}-4 \uparrow$ & Meijerink et al. $[67,69]$ \\
\hline Lactobacillus salivarius UCC118 & & & & $\uparrow$ & & Smelt [67] \\
\hline Lactobacillus rhamnosus LA68 & $\uparrow$ & & & & 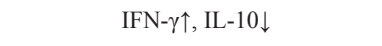 & Dimitrijevic [6] \\
\hline Lactobacillus plantarum CJLP133 & $\uparrow$ & & & & 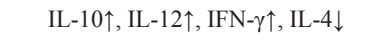 & Won $[8]$ \\
\hline Lactobacillus brevis HY7401 & $\uparrow$ & & & & $\begin{array}{l}\mathrm{IFN}-\gamma \uparrow, \mathrm{IL}-12 \uparrow, \mathrm{IL}-4 \uparrow, \mathrm{IL}-5 \uparrow, \mathrm{IL}-6 \downarrow \\
\mathrm{IL}-10 \downarrow\end{array}$ & Lee [7] \\
\hline $\begin{array}{c}\text { Lactobacillus rhamnosus GG ATCC } 53103 \text { \& Bifidobacterium } \\
\text { longum BB536 }\end{array}$ & $\uparrow$ & & & & 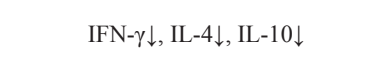 & Huang [9] \\
\hline Lactobacillus fermentum CJL-112 & $\uparrow$ & $\downarrow$ & & & 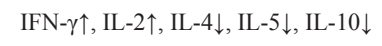 & Yeo [68] \\
\hline Lactobacillus salivarius HMI001 \& Lactobacillus casei Shirota & & $\downarrow$ & & & 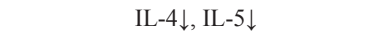 & Meijerink [69] \\
\hline Lactobacillus plantarum $\mathrm{nF} 1$ & $\uparrow$ & $\downarrow$ & $\uparrow$ & & 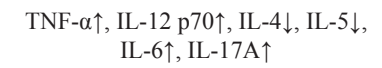 & Lee [89] \\
\hline Lactobacillus rhamnosus MTCC 5897 & $\uparrow$ & $\downarrow$ & & & 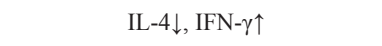 & Saliganti [106] \\
\hline Lactobacillus plantarum $\mathrm{K} 8$ & $\uparrow$ & & & & 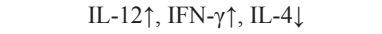 & $\operatorname{Kim}[107]$ \\
\hline
\end{tabular}

MCP: monocyte chemotactic protein; IL: interleukin; G-CSF: granulocyte-colony stimulating factor; TNF: tumor necrosis factor; IFN: interferon; TGF: transforming growth factor; CCL: C-C chemokine ligand.

three strains (CECT 7527, CECT 7528 and CECT 7529) reduced the plasma cholesterol levels with ox-LDL in hypercholesterolaemic patients [93]. Lactobacillus delbrueckii bulgaricus 2038 was also found to reduce LDL oxidation in F344 rats [94]. But another randomized, double-blind intervention in marathon runners revealed that Lactobacillus rhamnosus GG had no effect on regulation of ox-LDL, s-TRAP or serum antioxidants levels during the study [95]. However, a clinical trial in patients over 65 years old found that the ox-LDL level is inversely proportional to the number of Lactobacilli [96]. In addition, Yoon et al. found that Lactobacillus rhamnosus BFE5264 and Lactobacillus plantarum NR74 may block foam cell formation by cholesterol efflux and immune modulation in THP-1 macrophage cells [97].

Therefore, like the lymphocytes, inflammatory response of macrophages is different in various Lactobacillus strains, and it is vital that the appropriate strains are used to study anti-atherogenetic effects (Table 2).

\section{Inflammatory response of Lactobacilli in dendritic cells}

Lactobacilli has a significant influence on DCrelated inflammation that are strain dependent (Table 3). For instance, some strains, such as Lactobacillus casei, Lactobacillus acidophilus NCFM, Lactobacillus murinus, and Lactobacillus salivarius promote expression of inflammatory cytokines and co-stimulatory molecules more significantly than others, such as Lactobacillus helveticus LH-2, and Lactobacillus acidophilus La-115
[98, 99]. However, Lactobacillus plantarum OLL2712, Lactobacillus rhamnosus OLL2838, Lactobacillus reuteri 5289, Lactobacillus paracasei CBA L74, and Lactobacillus paracasei L9 induced anti-inflammatory cytokines in DCs, like IL-10, to exhibit anti-inflammatory effects [63, 85, 100-102]. Furthermore, Zagato et al. found that the suppressive effects of Lactobacillus paracasei CBA L74 on inflammation are independent of inactivated bacteria, but respond to metabolic products released during the fermentation process [102].

In fact, the influence of inflammatory regulation on DCs by Lactobacilli is complicated due to the fact that a single strain can induce pro-inflammatory and anti-inflammatory cytokines simultaneously $[103$, 104]. Moreover, the immune-modulating properties may rely on the host's genetic background [104]. A study in vitro showed that different strains and concentrations of Lactobacilli influence factors of DC-related inflammation [105]. After treating DCs with one of three concentrations of Lactobacilli (1, 10, and $100 \mu \mathrm{g} / \mathrm{ml}$ ), Christensen et al. found that the levels of pro-inflammatory factors, such as IL-12, IL-6 and TNF- $\alpha$, was highest in $\sim 10 \mu \mathrm{g}$ / $\mathrm{ml}$ while IL-10 was highest in the high bacteria concentration. The study also found that Lactobacillus reuteri inhibited Lactobacillus casei-induced IL-12, IL- 6 and TNF- $\alpha$ production in a dose-dependent manner [105]. Lactobacillus reuteri also inhibited the upregulation of CD86 (a co-stimulatory factor that induces T-lymphocyte proliferation and IL-2 production) induced by Lactobacillus casei. 
Table 2: Inflammatory response of Lactobacilli in macrophages

\begin{tabular}{|c|c|c|c|c|c|}
\hline Strains & $\begin{array}{c}\text { Macrophage } \\
\text { number }\end{array}$ & $\begin{array}{c}\mathrm{M} 1 / \mathrm{M} 2 \\
\text { ratio }\end{array}$ & Cholesterol & $\begin{array}{c}\text { Inflammatory cytokines or biochemical } \\
\text { markers }\end{array}$ & Reference \\
\hline Lactobacillus gasseri SBT2055 & $\downarrow$ & $\downarrow$ & & CCL $2 \downarrow$, CCR $2 \downarrow, \mathrm{LEP} \downarrow$ & Ukibe [81] \\
\hline Lactobacillus paracasei LPC4 & $\downarrow$ & $\downarrow$ & & $\begin{array}{c}\text { TLR- } 4 \downarrow, \text { NOX- } 4 \downarrow, \text { TNF- } \alpha \downarrow, \text { MCP- } 1 \downarrow, \text { IL- } 4 \downarrow, \\
\text { PPAR- } \gamma \downarrow, \text { PPAR- } \delta \downarrow,\end{array}$ & Sohn $[82]$ \\
\hline Lactobacillus plantarum CLP-0611 & & $\downarrow$ & & 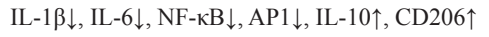 & Jang [83] \\
\hline Lactobacillus brevis G-101 & & $\downarrow$ & & IL-10个, IL-1 $\beta \downarrow$, IL- $6 \downarrow$, TNF- $\alpha \downarrow$, NF- $\kappa$ B $\downarrow$ & Jang [84] \\
\hline Lactobacillus plantarum OLL2712 & & & & IL-10个, IL-6 $\downarrow$, TNF- $\alpha \downarrow$, MCP- $1 \downarrow$ & Toshimitsu [85] \\
\hline Lactobacillus rhamnosus ATCC 7469 & & & & 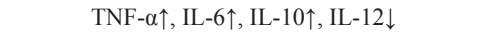 & Jorjao $[86]$ \\
\hline Lactobacillus rhamnosus GG MTCC 1408 & & & & IL-10个, TNF- $\alpha \downarrow$ & Divyashri [87] \\
\hline Lactobacillus helveticus NS8 & & & & IL-10个 & Rong [88] \\
\hline Lactobacillus plantarum $\mathrm{nF} 1$ & & & & 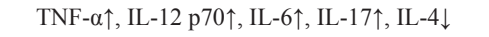 & Lee [89] \\
\hline Lactobacillus acidophilus JTB05 & & & & IFN- $\gamma \uparrow$ & Quinteiro-Filho [90] \\
\hline Lactobacillus salivarius JTB07 & & & & $\mathrm{IFN}-\gamma \uparrow, \mathrm{IL}-1 \beta \uparrow, \mathrm{IL}-6 \uparrow, \mathrm{IL}-8 \uparrow, \mathrm{IL}-12 \uparrow$ & Quinteiro-Filho [90] \\
\hline Lactobacillus reuteri JTB07 & & & & $\mathrm{IL}-1 \beta \uparrow, \mathrm{IL}-6 \uparrow, \mathrm{IL}-8 \uparrow, \mathrm{IL}-12 \uparrow$ & Quinteiro-Filho [90] \\
\hline Lactobacillus rhamnosus NutRes1 & & & & $\begin{array}{c}\text { IL-1 } \beta \downarrow, \text { IL-6 } \downarrow, \text { IL-10 } \downarrow, \text { IL-23 } \downarrow, \text { TNF- } \alpha \downarrow, \\
\text { CXCL-8 } \downarrow, \text { HMGB } 1 \downarrow\end{array}$ & Mortaz [91] \\
\hline Lactobacillus paracasei & & & cholesteryl-esters $\downarrow$ & 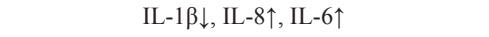 & Trasino $[92]$ \\
\hline $\begin{array}{l}\text { Lactobacillus plantarum mixture (CECT } 7527 \text {, } \\
\text { CECT } 7528 \text { and CECT 7529) }\end{array}$ & & & $\mathrm{TC} \downarrow, \mathrm{LDL} \downarrow, \mathrm{ox}-\mathrm{LDL} \downarrow$ & & Fuentes [93][49] \\
\hline Lactobacillus delbrueckii bulgaricus 2038 & & & ox-LDL $\downarrow$ & & Terahara [94] \\
\hline Intestinal Lactobacillus sp. & & & ox-LDL $\downarrow$ & & Mikelsaar [96] \\
\hline $\begin{array}{l}\text { Lactobacillus rhamnosus BFE5264 and } \\
\text { Lactobacillus plantarum NR74 }\end{array}$ & & & $\begin{array}{l}\text { cholesterol efflux } \uparrow, \\
\quad \text { foam cells } \downarrow\end{array}$ & IL- $1 \beta \downarrow, \mathrm{TNF}-\alpha \downarrow, \mathrm{LXR} \uparrow, \mathrm{ABCA} 1 \uparrow, \mathrm{ABCG} 1 \uparrow$ & Yoon $[97]$ \\
\hline
\end{tabular}

CCL: C-C chemokine ligand; CCR: C-C chemokine receptor; LEP: leptin; TLR: Toll-like receptor; NOX: NADPH oxidase; TNF: tumor necrosis factor; MCP: monocyte chemotactic protein; IL: interleukin; PPAR: peroxisome proliferator activated receptor; LXR: liver X receptor; ABCA1: ATP-binding cassette transporter A1; ABCG1: ATP-binding cassette transporter G1; CXCL: C-X-C motif chemokine.

Table 3: Inflammatory response of Lactobacillus in dendritic cells

\begin{tabular}{|c|c|c|}
\hline Strains & Inflammatory cytokines or biochemical markers & Reference \\
\hline Lactobacillus reuteri 5289 & $\begin{array}{l}\text { Inhibit Lactobacillus acidophilus NCFM- induced } \\
\qquad \text { IL-12p70 }\end{array}$ & Amar [101] \\
\hline Lactobacillus acidophilus NCFM & IL-12p70个, IL-10个 & Amar [101] \\
\hline Lactobacillus murinus & 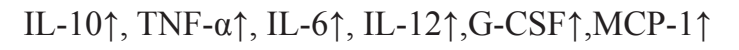 & Konieczna [98] \\
\hline Lactobacillus plantarum OLL2712 & IL-10个 & Toshimitsu [85] \\
\hline Lactobacillus rhamnosus OLL2838 & 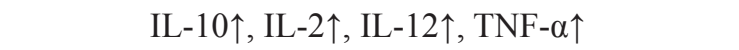 & Ogita $[100]$ \\
\hline Lactobacillus paracasei CBA L74 & IL-10个 & Zagato [102] \\
\hline Lactobacillus paracasei L9 & 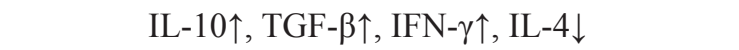 & Yang [63] \\
\hline Lactobacillus rhamnosus CRL1505 & $\mathrm{MHC}-\mathrm{II} \uparrow$ & Chiba [103] \\
\hline Lactobacillus reuteri DSM12246 & $\begin{array}{l}\text { IL-10个, inhibit Lactobacillus casei CHCC } 3137- \\
\text { induced IL-12, IL-6 and TNF- } \alpha\end{array}$ & Christensen [105] \\
\hline Lactobacillus casei CHCC3137 & 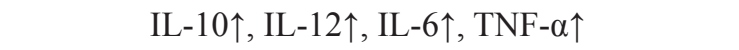 & Christensen [105] \\
\hline Lactobacillus plantarum Lb1 & 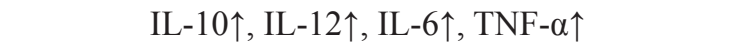 & Christensen [105] \\
\hline Lactobacillus fermentum Lb20 & 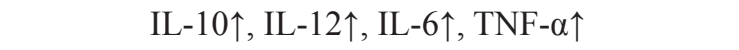 & Christensen [105] \\
\hline Lactobacillus plantarum $299 \mathrm{v}$ & 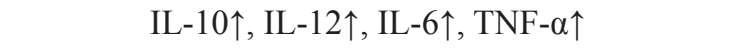 & Christensen [105] \\
\hline Lactobacillus johnsonii La1 & 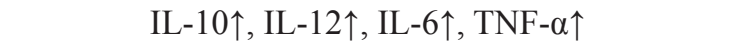 & Christensen [105] \\
\hline Lactobacillus gasseri SBT2055 & TGF- $\beta \uparrow, \mathrm{BAFF} \uparrow, \mathrm{IL}-10 \uparrow, \mathrm{IL}-6 \uparrow$ & Sakai [108] \\
\hline Lactobacillus jensenii TL2937 & MHC-II $\uparrow, \mathrm{CD} 80 / 86 \uparrow, \mathrm{IL}-10 \uparrow$ & Suda [109] \\
\hline Lactobacillus rhamnosus CNCM I-4036 & 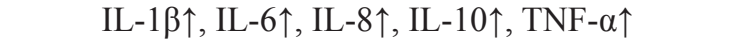 & Bermudez-Brito [110] \\
\hline
\end{tabular}

MCP: monocyte chemotactic protein; IL: interleukin; G-CSF: granulocyte-colony stimulating factor; TNF: tumor necrosis factor; IFN: interferon; TGF: transforming growth factor; MHC: major histocompatibility complex; BAFF: B cell activation factor.

\section{CONCLUSION}

Immune cells play a key role in the progression of atherogenesis, which are involved in T-lymphocytes,
B-lymphocytes, NK cells, DCs, monocytes/macrophages. Lactobacilli are proven regulators of the immune system. Considering the key role of inflammation in atherogenesis and the anti-atherogenetic effect of Lactobacilli, 


\section{Table 4: The effects of Lactobacilli in the progression of atherogenesis}

\begin{tabular}{|c|c|}
\hline Effects & Strains \\
\hline Anti-atherogenesis & $\begin{array}{l}\text { L. rhamnosus Lcr35, L. rhamnosus GG, L. casei ATCC 334, L. reuteri ATCC 23272, L. paracasei } \\
\text { L9, L. taiwanesis, L. plantarum WCFS1, L. salivarius UCC118, L. gasseri SBT2055, L. paracasei } \\
\text { LPC4, L. plantarum CLP-0611, L. brevis G-101, L. plantarum OLL2712, L. rhamnosus ATCC 7469, } \\
\text { L. rhamnosus GG MTCC 1408, L. helveticus NS8, L. rhamnosus NutRes1, L. plantarum mixture } \\
\text { (CECT } 7527, \text { CECT } 7528 \text { and CECT 7529), L. delbrueckii bulgaricus 2038, Intestinal L. sp., L. } \\
\text { rhamnosus BFE5264 and L. plantarum NR74, L. rhamnosus OLL2838, L. reuteri 5289, L. paracasei } \\
\text { CBA L74, L. reuteri DSM12246 }\end{array}$ \\
\hline Pro-atherogenesis & $\begin{array}{l}\text { L. rhamnosus LA68, L. plantarum CJLP133, L. brevis HY7401, L. rhamnosus GG ATCC } 53103 \text { \& } \\
\text { Bifidobacterium longum BB536, L. fermentum CJL-112, L. salivarius HMI001 \& L. casei Shirota, } \\
\text { L. plantarum } \mathrm{nF} 1 \text {, L. rhamnosus MTCC 5897, L. plantarum K8, L. acidophilus JTB05, L. salivarius } \\
\text { JTB07, L. reuteri JTB07, L. acidophilus NCFM, L. murinus, }\end{array}$ \\
\hline Not Sure & $\begin{array}{l}\text { L. paracasei, L. rhamnosus CRL1505, L. casei CHCC } 3137 \text {, L. plantarum Lb1, L. fermentum Lb20, } \\
\text { L. plantarum 299v, L. johnsonii La1, L. jensenii TL2937, L. rhamnosus CNCM I-4036 }\end{array}$ \\
\hline
\end{tabular}

immunoregulation for immune cells may be the mechanism by which the probiotic elicits atherogenesisrelated effects.

Recent studies found that immunoregulatory effects of Lactobacilli are strain-specific (Table 4). Some strains, like Lactobacillus rhamnosus Lcr35, decrease Th1 cell number and pro-inflammatory cytokines levels to inhibit the progression of atherogenesis. Other strains, like Lactobacillus brevis HY7401, upregulate Th1 cells and promote the secretion of pro-inflammatory cytokines which may accelerate the atherogenesis. The upregulation of Treg cell activity is also an important mechanism of anti-atherogenetic effects of Lactobacilli. Serveal strains, such as Lactobacillus rhamnosus Lcr35, Lactobacillus rhamnosus GG, Lactobacillus casei ATCC 334, Lactobacillus reuteri ATCC 23272, Lactobacillus paracasei L9, etc., are found to increase the Treg cell activity. In addition, inflammatory cytokines secreted by T-lymphocytes are also important part of immune response network. Some strains like Lactobacillus rhamnosus LA68 upregulate pro-inflammatory cytokines like IFN- $\gamma$ as well as downregulate anti-inflammatory cytokines like IL-10. Some other strains like Lactobacillus casei ATCC 334 can increase anti-inflammatory cytokines levels. Notably, some strains like Lactobacillus plantarum CJLP133 increase pro-inflammatory cytokines and antiinflammatory cytokines at the same time. So it increase the difficulty to derive the effects of Lactobacilli involved in atherogenesis.

Macrophages can differentiate into two subsets, pro-inflammatory subset M1 and anti-inflammatory subset M2. Some Lactobacillus strains can promote M1 differentiation or macrophage polarization to alter the M1/ $\mathrm{M} 2$ ratio. The influence on pro-inflammatory production levels of macrophages is also strain-specific. Some strains like Lactobacillus plantarum $\mathrm{nF} 1$ promote proinflammatory cytokines secretion and other strains inhibit them. Furthermore, some strains was found to reduce oxLDL level in human or rats.
DCs, a powerful T-lymphocyte activating factor, play a critical role in atherogenesis and can cause ASrelated adverse effects. Lactobacilli were revealed to inhibit DC-induced inflammation and stimulate DCs to secrete anti-inflammatory cytokines like IL-10. Several studies also revealed different inflammatory responses to various Lactobacillus strains and experimental models, including pro-inflammatory effects.

Lactobacilli strains can augment NK cell activity. TLR2/NF- $\kappa \mathrm{B}$ signaling pathway is involved in NK cell activity. But cytokines induced by Lactobacilli are strainspecific. The role of Lactobacilli in the atherogenesis is still unclear unless there is some direct evidence.

Similarly, the effects of Lactobacilli in the progression of atherogenesis via B-lymphocytes are in dispute, not only because of strain-specific immune response, but also the evidence about B-lymphocyte polarization induced by Lactobacilli or other direct evidence is absent.

Taken together, immune cells are very important pathways in atherogenesis, while Lactobacilli play their immunomodulatory effects to influence the progress of atherogenesis. But the direct study evidence, Lactobacilli promoting or inhibiting atherogenesis via immune cell pathways, is absent. Thus future studies are needed to explore the roles of immune cells in the atherogenesis, especially anti-atherogenetic effect, by Lactobacillus treatment subjects which may help to identify and properly utilize the appropriate strains.

\section{ACKNOWLEDGMENTS}

There was no financial support or funding for this article.

\section{CONFLICTS OF INTEREST}

All authors declare that there are no conflicts of interest. 


\section{REFERENCES}

1. Legein B, Temmerman L, Biessen EA, Lutgens E. Inflammation and immune system interactions in atherosclerosis. Cell Mol Life Sci. 2013; 70:3847-69. doi: 10.1007/s00018-013-1289-1.

2. Yilmaz A, Reiss C, Tantawi O, Weng A, Stumpf C, Raaz D, Ludwig J, Berger T, Steinkasserer A, Daniel WG, Garlichs CD. HMG-CoA reductase inhibitors suppress maturation of human dendritic cells: new implications for atherosclerosis. Atherosclerosis. 2004; 172:85-93.

3. Tomaro-Duchesneau C, Saha S, Malhotra M, Jones ML, Labbe A, Rodes L, Kahouli I, Prakash S. Effect of orally administered L. fermentum NCIMB 5221 on markers of metabolic syndrome: an in vivo analysis using ZDF rats. Appl Microbiol Biotechnol. 2014; 98:115-26. doi: 10.1007/ s00253-013-5252-8.

4. Pan DD, Zeng XQ, Yan YT. Characterisation of Lactobacillus fermentum SM-7 isolated from koumiss, a potential probiotic bacterium with cholesterol-lowering effects. J Sci Food Agric. 2011; 91:512-8. doi: 10.1002/jsfa.4214.

5. Bhathena J, Martoni C, Kulamarva A, Urbanska AM, Malhotra M, Prakash S. Orally delivered microencapsulated live probiotic formulation lowers serum lipids in hypercholesterolemic hamsters. J Med Food. 2009; 12:310-9. doi: 10.1089/jmf.2008.0166.

6. Dimitrijevic R, Ivanovic N, Mathiesen G, Petrusic V, Zivkovic I, Djordjevic B, Dimitrijevic L. Effects of Lactobacillus rhamnosus LA68 on the immune system of C57BL/6 mice upon oral administration. J Dairy Res. 2014; 81:202-7. doi: 10.1017/S0022029914000028.

7. Lee J, Bang J, Woo HJ. Effect of orally administered Lactobacillus brevis HY7401 in a food allergy mouse model. J Microbiol Biotechnol. 2013; 23:1636-40.

8. Won TJ, Kim B, Song DS, Lim YT, Oh ES, Lee DI, Park ES, Min H, Park SY, Hwang KW. Modulation of Th1/Th2 balance by Lactobacillus strains isolated from Kimchi via stimulation of macrophage cell line J774A.1 in vitro. J Food Sci. 2011; 76:H55-61. doi: 10.1111/j.17503841.2010.02031.x.

9. Huang J, Zhong Y, Cai W, Zhang H, Tang W, Chen B. The effects of probiotics supplementation timing on an ovalbuminsensitized rat model. FEMS Immunol Med Microbiol. 2010; 60:132-41. doi: 10.1111/j.1574-695X.2010.00727.x.

10. Bouhlel MA, Derudas B, Rigamonti E, Dievart R, Brozek J, Haulon S, Zawadzki C, Jude B, Torpier G, Marx N, Staels B, Chinetti-Gbaguidi G. PPARgamma activation primes human monocytes into alternative M2 macrophages with anti-inflammatory properties. Cell Metab. 2007; 6:137-43. doi: 10.1016/j.cmet.2007.06.010.

11. Chinetti-Gbaguidi G, Baron M, Bouhlel MA, Vanhoutte J, Copin C, Sebti Y, Derudas B, Mayi T, Bories G, Tailleux A, Haulon S, Zawadzki C, Jude B, et al. Human atherosclerotic plaque alternative macrophages display low cholesterol handling but high phagocytosis because of distinct activities of the PPARgamma and LXRalpha pathways. Circ Res. 2011; 108:985-95. doi: 10.1161/ CIRCRESAHA.110.233775.

12. Koenen RR, Weber C. Chemokines: established and novel targets in atherosclerosis. EMBO Mol Med. 2011; 3:713-25. doi: 10.1002/emmm.201100183.

13. Areschoug $\mathrm{T}$, Waldemarsson $\mathrm{J}$, Gordon S. Evasion of macrophage scavenger receptor A-mediated recognition by pathogenic streptococci. Eur J Immunol. 2008; 38:3068-79. doi: 10.1002/eji.200838457.

14. Businaro R, Tagliani A, Buttari B, Profumo E, Ippoliti F, Di Cristofano C, Capoano R, Salvati B, Rigano R. Cellular and molecular players in the atherosclerotic plaque progression. Ann N Y Acad Sci. 2012; 1262:134-41. doi: 10.1111/j.1749-6632.2012.06600.x.

15. Murray PJ, Wynn TA. Protective and pathogenic functions of macrophage subsets. Nat Rev Immunol. 2011; 11:723-37. doi: 10.1038/nri3073.

16. Tiemessen MM, Jagger AL, Evans HG, van Herwijnen MJ, John S, Taams LS. CD4+CD25+Foxp3+ regulatory $\mathrm{T}$ cells induce alternative activation of human monocytes/ macrophages. Proc Natl Acad Sci USA. 2007; 104:19446-51. doi: 10.1073/pnas.0706832104.

17. Feig JE, Parathath S, Rong JX, Mick SL, Vengrenyuk Y, Grauer L, Young SG, Fisher EA. Reversal of hyperlipidemia with a genetic switch favorably affects the content and inflammatory state of macrophages in atherosclerotic plaques. Circulation. 2011; 123:989-98. doi: 10.1161/ CIRCULATIONAHA.110.984146.

18. Newton AH, Benedict SH. Low density lipoprotein promotes human naive $\mathrm{T}$ cell differentiation to $\mathrm{Th} 1$ cells. Hum Immunol. 2014; 75:621-8. doi: 10.1016/j. humimm.2014.04.017.

19. Ait-Oufella H, Taleb S, Mallat Z, Tedgui A. Recent advances on the role of cytokines in atherosclerosis. Arterioscler Thromb Vasc Biol. 2011; 31:969-79. doi: 10.1161/ATVBAHA.110.207415.

20. Binder CJ, Hartvigsen K, Chang MK, Miller M, Broide D, Palinski W, Curtiss LK, Corr M, Witztum JL. IL-5 links adaptive and natural immunity specific for epitopes of oxidized LDL and protects from atherosclerosis. J Clin Invest. 2004; 114:427-37. doi: 10.1172/JCI20479.

21. Cardilo-Reis L, Gruber S, Schreier SM, Drechsler M, Papac-Milicevic N, Weber C, Wagner O, Stangl H, Soehnlein O, Binder CJ. Interleukin-13 protects from atherosclerosis and modulates plaque composition by skewing the macrophage phenotype. EMBO Mol Med. 2012; 4:1072-86. doi: 10.1002/emmm.201201374.

22. Davenport P, Tipping PG. The role of interleukin-4 and interleukin-12 in the progression of atherosclerosis in apolipoprotein E-deficient mice. Am J Pathol. 2003; 163:1117-25. doi: 10.1016/ S0002-9440(10)63471-2. 
23. Wigren M, Nilsson J, Kolbus D. Lymphocytes in atherosclerosis. Clin Chim Acta. 2012; 413: 1562-8. doi: 10.1016/j.cca.2012.04.031.

24. Taleb S, Tedgui A, Mallat Z. IL-17 and Th17 cells in atherosclerosis: subtle and contextual roles. Arterioscler Thromb Vasc Biol. 2015; 35: 258-64. doi: 10.1161/ ATVBAHA.114.303567.

25. Erbel C, Chen L, Bea F, Wangler S, Celik S, Lasitschka F, Wang Y, Bockler D, Katus HA, Dengler TJ. Inhibition of IL-17A attenuates atherosclerotic lesion development in apoE-deficient mice. J Immunol. 2009; 183:8167-75. doi: 10.4049/jimmunol.0901126.

26. Gao Q, Jiang Y, Ma T, Zhu F, Gao F, Zhang P, Guo C, Wang Q, Wang X, Ma C, Zhang Y, Chen W, Zhang L. A critical function of Th17 proinflammatory cells in the development of atherosclerotic plaque in mice. J Immunol. 2010; 185:5820-7. doi: 10.4049/jimmunol.1000116.

27. Madhur MS, Funt SA, Li L, Vinh A, Chen W, Lob HE, Iwakura Y, Blinder Y, Rahman A, Quyyumi AA, Harrison DG. Role of interleukin 17 in inflammation, atherosclerosis, and vascular function in apolipoprotein e-deficient mice. Arterioscler Thromb Vasc Biol. 2011; 31:1565-72. doi: 10.1161/ATVBAHA.111.227629.

28. Wang Z, Lee J, Zhang Y, Wang H, Liu X, Shang F, Zheng Q. Increased Th17 cells in coronary artery disease are associated with neutrophilic inflammation. Scand Cardiovasc J. 2011; 45:54-61. doi: 10.3109/14017431.2010.491123.

29. Cheng X, Yu X, Ding YJ, Fu QQ, Xie JJ, Tang TT, Yao R, Chen Y, Liao YH. The Th17/Treg imbalance in patients with acute coronary syndrome. Clin Immunol. 2008; 127:89-97. doi: 10.1016/j.clim.2008.01.009.

30. Smits HH, Engering A, van der Kleij D, de Jong EC, Schipper K, van Capel TM, Zaat BA, Yazdanbakhsh M, Wierenga EA, van Kooyk Y, Kapsenberg ML. Selective probiotic bacteria induce IL-10-producing regulatory $\mathrm{T}$ cells in vitro by modulating dendritic cell function through dendritic cell-specific intercellular adhesion molecule 3-grabbing nonintegrin. J Allergy Clin Immunol. 2005; 115:1260-7. doi: 10.1016/j.jaci.2005.03.036.

31. Spitz C, Winkels H, Burger C, Weber C, Lutgens E, Hansson GK, Gerdes N. Regulatory T cells in atherosclerosis: critical immune regulatory function and therapeutic potential. Cell Mol Life Sci. 2016; 73:901-22. doi: 10.1007/s00018015-2080-2.

32. Taub DD, Proost P, Murphy WJ, Anver M, Longo DL, van Damme J, Oppenheim JJ. Monocyte chemotactic protein-1 (MCP-1), -2, and -3 are chemotactic for human T lymphocytes. J Clin Invest. 1995; 95:1370-6. doi: 10.1172/ JCI117788.

33. Umehara H, Bloom ET, Okazaki T, Nagano Y, Yoshie O, Imai T. Fractalkine in vascular biology: from basic research to clinical disease. Arterioscler Thromb Vasc Biol. 2004; 24:34-40. doi: 10.1161/01.ATV.0000095360.62479.1F.
34. Clerc G, Rouz PM. Lymphocyte subsets in severe atherosclerosis before revascularization. Ann Intern Med. 1997; 126: 1004-5.

35. Ludatscher RM, Silbermann M. Abnormalities of intramuscular nerves in old mice: an ultrastructural study. Exp Gerontol. 1988; 23:127-37.

36. Jonasson L, Backteman K, Ernerudh J. Loss of natural killer cell activity in patients with coronary artery disease. Atherosclerosis. 2005; 183:316-21. doi: 10.1016/j. atherosclerosis.2005.03.011.

37. Backteman K, Andersson C, Dahlin LG, Ernerudh J, Jonasson L. Lymphocyte subpopulations in lymph nodes and peripheral blood: a comparison between patients with stable angina and acute coronary syndrome. PLoS One. 2012; 7:e32691. doi: 10.1371/journal.pone.0032691.

38. Backteman K, Ernerudh J, Jonasson L. Natural killer (NK) cell deficit in coronary artery disease: no aberrations in phenotype but sustained reduction of NK cells is associated with low-grade inflammation. Clin Exp Immunol. 2014; 175:104-12. doi: 10.1111/cei.12210.

39. Schiller NK, Boisvert WA, Curtiss LK. Inflammation in atherosclerosis: lesion formation in LDL receptor-deficient mice with perforin and Lyst(beige) mutations. Arterioscler Thromb Vasc Biol. 2002; 22:1341-6.

40. Grasset EK, Duhlin A, Agardh HE, Ovchinnikova O, Hagglof T, Forsell MN, Paulsson-Berne G, Hansson GK, Ketelhuth DF, Karlsson MC. Sterile inflammation in the spleen during atherosclerosis provides oxidation-specific epitopes that induce a protective B-cell response. Proc Natl Acad Sci USA. 2015; 112:E2030-8. doi: 10.1073/ pnas. 1421227112

41. Sage AP, Tsiantoulas D, Baker L, Harrison J, Masters L, Murphy D, Loinard C, Binder CJ, Mallat Z. BAFF receptor deficiency reduces the development of atherosclerosis in mice - brief report. Arterioscler Thromb Vasc Biol. 2012; 32:1573-6. doi: 10.1161/ATVBAHA.111.244731.

42. Huan T, Zhang B, Wang Z, Joehanes R, Zhu J, Johnson AD, Ying S, Munson PJ, Raghavachari N, Wang R, Liu P, Courchesne P, Hwang SJ, et al. A systems biology framework identifies molecular underpinnings of coronary heart disease. Arterioscler Thromb Vasc Biol. 2013; 33:1427-34. doi: 10.1161/ATVBAHA.112.300112.

43. Tsiantoulas D, Diehl CJ, Witztum JL, Binder CJ. B cells and humoral immunity in atherosclerosis. Circ Res. 2014; 114: 1743-56. doi: 10.1161/CIRCRESAHA.113.301145.

44. Gigante B, Leander K, Vikstrom M, Baldassarre D, Veglia F, Strawbridge RJ, McLeod O, Gertow K, Sennblad B, Shah S, Zabaneh D, Humphries SE, Kauhanen J, et al. Low levels of IgM antibodies against phosphorylcholine are associated with fast carotid intima media thickness progression and cardiovascular risk in men. Atherosclerosis. 2014; 236:394-9. doi: 10.1016/j. atherosclerosis.2014.07.030. 
45. Goncalves I, Gronholdt ML, Soderberg I, Ares MP, Nordestgaard BG, Bentzon JF, Fredrikson GN, Nilsson J. Humoral immune response against defined oxidized low-density lipoprotein antigens reflects structure and disease activity of carotid plaques. Arterioscler Thromb Vasc Biol. 2005; 25:1250-5. doi: 10.1161/01. ATV.0000166518.96137.38.

46. Kyaw T, Tay C, Hosseini H, Kanellakis P, Gadowski T, MacKay F, Tipping P, Bobik A, Toh BH. Depletion of B2 but not B1a B cells in BAFF receptor-deficient ApoE mice attenuates atherosclerosis by potently ameliorating arterial inflammation. PLoS One. 2012; 7:e29371. doi: 10.1371/ journal.pone.0029371.

47. Borchers AT, Selmi C, Meyers FJ, Keen CL, Gershwin ME. Probiotics and immunity. J Gastroenterol. 2009; 44:26-46. doi: 10.1007/s00535-008-2296-0.

48. Zeuthen LH, Christensen HR, Frokiaer H. Lactic acid bacteria inducing a weak interleukin-12 and tumor necrosis factor alpha response in human dendritic cells inhibit strongly stimulating lactic acid bacteria but act synergistically with gram-negative bacteria. Clin Vaccine Immunol. 2006; 13:365-75. doi: 10.1128/CVI.13.3.365375.2006 .

49. Bobryshev YV. Dendritic cells and their involvement in atherosclerosis. Curr Opin Lipidol. 2000; 11:511-7.

50. Lord RS, Bobryshev YV. Clustering of dendritic cells in athero-prone areas of the aorta. Atherosclerosis. 1999; 146:197-8.

51. Hansson GK. Immune mechanisms in atherosclerosis. Arterioscler Thromb Vasc Biol. 2001; 21:1876-90.

52. Hansson GK, Libby P, Schonbeck U, Yan ZQ. Innate and adaptive immunity in the pathogenesis of atherosclerosis. Circ Res. 2002; 91:281-91.

53. Kofler S, Sisic Z, Shvets N, Lohse P, Weis M. Expression of circulatory dendritic cells and regulatory T-cells in patients with different subsets of coronary artery disease. J Cardiovasc Pharmacol. 2011; 57:542-9. doi: 10.1097/ FJC.0b013e3182124c53.

54. Laffont S, Siddiqui KR, Powrie F. Intestinal inflammation abrogates the tolerogenic properties of MLN CD103+ dendritic cells. Eur J Immunol. 2010; 40:1877-83. doi: 10.1002/eji.200939957.

55. Worbs T, Hammerschmidt SI, Forster R. Dendritic cell migration in health and disease. Nat Rev Immunol. 2017; 17:30-48. doi: 10.1038/nri.2016.116.

56. Subramanian M, Thorp E, Hansson GK, Tabas I. Tregmediated suppression of atherosclerosis requires MYD88 signaling in DCs. J Clin Invest. 2013; 123:179-88. doi: 10.1172/JCI64617.

57. Daissormont IT, Christ A, Temmerman L, Sampedro Millares S, Seijkens T, Manca M, Rousch M, Poggi M, Boon L, van der Loos C, Daemen M, Lutgens E, Halvorsen B, et al. Plasmacytoid dendritic cells protect against atherosclerosis by tuning $\mathrm{T}$-cell proliferation and activity. Circ Res. 2011; 109:1387-95. doi: 10.1161/ CIRCRESAHA.111.256529.

58. Karimi $\mathrm{K}$, Inman $\mathrm{MD}$, Bienenstock $\mathrm{J}$, Forsythe $\mathrm{P}$. Lactobacillus reuteri-induced regulatory $\mathrm{T}$ cells protect against an allergic airway response in mice. Am J Respir Crit Care Med. 2009; 179:186-93. doi: 10.1164/ rccm.200806-9510C.

59. Kim HJ, Kim YJ, Kang MJ, Seo JH, Kim HY, Jeong SK, Lee SH, Kim JM, Hong SJ. A novel mouse model of atopic dermatitis with epicutaneous allergen sensitization and the effect of Lactobacillus rhamnosus. Exp Dermatol. 2012; 21:672-5. doi: 10.1111/j.1600-0625.2012.01539.x.

60. Jang SO, Kim HJ, Kim YJ, Kang MJ, Kwon JW, Seo JH, Kim HY, Kim BJ, Yu J, Hong SJ. Asthma Prevention by Lactobacillus Rhamnosus in a Mouse Model is Associated With CD4(+)CD25(+)Foxp3(+) T Cells. Allergy Asthma Immunol Res. 2012; 4:150-6. doi: 10.4168/ aair.2012.4.3.150.

61. Shah MM, Saio M, Yamashita H, Tanaka H, Takami T, Ezaki T, Inagaki N. Lactobacillus acidophilus strain L-92 induces CD4(+)CD25(+)Foxp3(+) regulatory T cells and suppresses allergic contact dermatitis. Biol Pharm Bull. 2012; 35:612-6.

62. Reynolds LA, Smith KA, Filbey KJ, Harcus Y, Hewitson JP, Redpath SA, Valdez Y, Yebra MJ, Finlay BB, Maizels RM. Commensal-pathogen interactions in the intestinal tract: lactobacilli promote infection with, and are promoted by, helminth parasites. Gut Microbes. 2014; 5:522-32. doi: 10.4161/gmic.32155.

63. Yang J, Ren F, Zhang H, Jiang L, Hao Y, Luo X. Induction of Regulatory Dendritic Cells by Lactobacillus paracasei L9 Prevents Allergic Sensitization to Bovine betaLactoglobulin in Mice. J Microbiol Biotechnol. 2015; 25:1687-96. doi: 10.4014/jmb.1503.03022.

64. Kim HJ, Kim YJ, Lee SH, Yu J, Jeong SK, Hong SJ. Effects of Lactobacillus rhamnosus on allergic march model by suppressing Th2, Th17, and TSLP responses via CD4(+) CD25(+)Foxp3(+) Tregs. Clin Immunol. 2014; 153:178-86. doi: 10.1016/j.clim.2014.04.008.

65. Khailova L, Baird $\mathrm{CH}$, Rush AA, McNamee EN, Wischmeyer PE. Lactobacillus rhamnosus GG improves outcome in experimental pseudomonas aeruginosa pneumonia: potential role of regulatory $\mathrm{T}$ cells. Shock. 2013; 40:496-503. doi: 10.1097/SHK.0000000000000066.

66. Tiittanen M, Keto J, Haiko J, Matto J, Partanen J, Lahteenmaki K. Interaction with intestinal epithelial cells promotes an immunosuppressive phenotype in Lactobacillus casei. PLoS One. 2013; 8:e78420. doi: 10.1371/journal.pone.0078420.

67. Smelt MJ, de Haan BJ, Bron PA, van Swam I, Meijerink M, Wells JM, Faas MM, de Vos P. Probiotics can generate FoxP3 T-cell responses in the small intestine and simultaneously inducing CD4 and CD8 T cell activation in the large intestine. PLoS One. 2013; 8:e68952. doi: 10.1371/journal.pone.0068952. 
68. Yeo JM, Lee HJ, Kim JW, Lee JB, Park SY, Choi IS, Song CS. Lactobacillus fermentum CJL-112 protects mice against influenza virus infection by activating T-helper 1 and eliciting a protective immune response. Int Immunopharmacol. 2014; 18:50-4. doi: 10.1016/j. intimp.2013.10.020.

69. Meijerink M, Wells JM, Taverne N, de Zeeuw Brouwer ML, Hilhorst B, Venema K, van Bilsen J. Immunomodulatory effects of potential probiotics in a mouse peanut sensitization model. FEMS Immunol Med Microbiol. 2012; 65:488-96. doi: 10.1111/j.1574-695X.2012.00981.x.

70. Hosoya T, Sakai F, Yamashita M, Shiozaki T, Endo T, Ukibe K, Uenishi H, Kadooka Y, Moriya T, Nakagawa H, Nakayama Y, Miyazaki T. Lactobacillus helveticus SBT2171 inhibits lymphocyte proliferation by regulation of the JNK signaling pathway. PLoS One. 2014; 9:e108360. doi: 10.1371/journal.pone.0108360.

71. Won TJ, Kim B, Oh ES, Bang JS, Lee YJ, Yoo JS, $\mathrm{Yu}$ H, Yoon J, Hyung KE, Park SY, Hwang KW. Immunomodulatory activity of Lactobacillus strains isolated from fermented vegetables and infant stool. Can J Physiol Pharmacol. 2011; 89:429-34. doi: 10.1139/y11-047.

72. Mane J, Pedrosa E, Loren V, Gassull MA, Espadaler J, Cune J, Audivert S, Bonachera MA, Cabre E. A mixture of Lactobacillus plantarum CECT 7315 and CECT 7316 enhances systemic immunity in elderly subjects. A doseresponse, double-blind, placebo-controlled, randomized pilot trial. Nutr Hosp. 2011; 26:228-35.

73. Matsusaki T, Takeda S, Takeshita M, Arima Y, TsendAyush C, Oyunsuren T, Sugita C, Yoshida H, Watanabe W, Kurokawa M. Augmentation of T helper type 1 immune response through intestinal immunity in murine cutaneous herpes simplex virus type 1 infection by probiotic Lactobacillus plantarum strain 06CC2. Int Immunopharmacol. 2016; 39:320-7. doi: 10.1016/j.intimp.2016.08.001.

74. Makino S, Sato A, Goto A, Nakamura M, Ogawa M, Chiba Y, Hemmi J, Kano H, Takeda K, Okumura K, Asami Y. Enhanced natural killer cell activation by exopolysaccharides derived from yogurt fermented with Lactobacillus delbrueckii ssp. bulgaricus OLL1073R-1. J Dairy Sci. 2016; 99:915-23. doi: 10.3168/jds.2015-10376.

75. Shida K, Sato T, Iizuka R, Hoshi R, Watanabe O, Igarashi T, Miyazaki K, Nanno M, Ishikawa F. Daily intake of fermented milk with Lactobacillus casei strain Shirota reduces the incidence and duration of upper respiratory tract infections in healthy middle-aged office workers. Eur J Nutr. 2017; 56:45-53. doi: 10.1007/s00394-015-1056-1.

76. Jang SE, Joh EH, Ahn YT, Huh CS, Han MJ, Kim DH. Lactobacillus casei HY7213 ameliorates cyclophosphamide-induced immunosuppression in mice by activating NK, cytotoxic $\mathrm{T}$ cells and macrophages. Immunopharmacol Immunotoxicol. 2013; 35:396-402. doi: 10.3109/08923973.2013.789055.

77. Soltan Dallal MM, Yazdi MH, Holakuyee M, Hassan ZM, Abolhassani M, Mahdavi M. Lactobacillus casei ssp. casei induced Th1 cytokine profile and natural killer cells activity in invasive ductal carcinoma bearing mice. Iran J Allergy Asthma Immunol. 2012; 11:183-9. doi: 011.02/ ijaai.183189.

78. Lee YN, Youn HN, Kwon JH, Lee DH, Park JK, Yuk SS, Erdene-Ochir TO, Kim KT, Lee JB, Park SY, Choi IS, Song CS. Sublingual administration of Lactobacillus rhamnosus affects respiratory immune responses and facilitates protection against influenza virus infection in mice. Antiviral Res. 2013; 98:284-90. doi: 10.1016/j. antiviral.2013.03.013.

79. Dong H, Rowland I, Thomas LV, Yaqoob P. Immunomodulatory effects of a probiotic drink containing Lactobacillus casei Shirota in healthy older volunteers. Eur J Nutr. 2013; 52: 1853-63. doi: 10.1007/s00394-012-0487-1.

80. Dong H, Rowland I, Yaqoob P. Comparative effects of six probiotic strains on immune function in vitro. Br J Nutr. 2012; 108:459-70. doi: 10.1017/S0007114511005824.

81. Ukibe K, Miyoshi M, Kadooka Y. Administration of Lactobacillus gasseri SBT2055 suppresses macrophage infiltration into adipose tissue in diet-induced obese mice. $\mathrm{Br}$ J Nutr. 2015; 114:1180-7. doi: 10.1017/S0007114515002627.

82. Sohn W, Jun DW, Lee KN, Lee HL, Lee OY, Choi HS, Yoon BC. Lactobacillus paracasei Induces M2-Dominant Kupffer Cell Polarization in a Mouse Model of Nonalcoholic Steatohepatitis. Dig Dis Sci. 2015; 60:3340-50. doi: 10.1007/s10620-015-3770-1.

83. Jang SE, Han MJ, Kim SY, Kim DH. Lactobacillus plantarum CLP-0611 ameliorates colitis in mice by polarizing M1 to M2-like macrophages. Int Immunopharmacol. 2014; 21:186-92. doi: 10.1016/j. intimp.2014.04.021.

84. Jang SE, Hyam SR, Han MJ, Kim SY, Lee BG, Kim DH. Lactobacillus brevis G-101 ameliorates colitis in mice by inhibiting NF-kappaB, MAPK and AKT pathways and by polarizing M1 macrophages to M2-like macrophages. J Appl Microbiol. 2013; 115:888-96. doi: 10.1111/jam.12273.

85. Toshimitsu T, Mochizuki J, Ikegami S, Itou H. Identification of a Lactobacillus plantarum strain that ameliorates chronic inflammation and metabolic disorders in obese and type 2 diabetic mice. J Dairy Sci. 2016; 99:933-46. doi: 10.3168/ jds.2015-9916.

86. Jorjao AL, de Oliveira FE, Leao MV, Carvalho CA, Jorge AO, de Oliveira LD. Live and Heat-Killed Lactobacillus rhamnosus ATCC 7469 May Induce Modulatory Cytokines Profiles on Macrophages RAW 264.7. ScientificWorldJournal. 2015; 2015:716749. doi: 10.1155/2015/716749.

87. Divyashri G, Krishna G, Muralidhara, Prapulla SG. Probiotic attributes, antioxidant, anti-inflammatory and neuromodulatory effects of Enterococcus faecium CFR 3003: in vitro and in vivo evidence. J Med Microbiol. 2015; 64:1527-40. doi: 10.1099/jmm.0.000184.

88. Rong J, Zheng H, Liu M, Hu X, Wang T, Zhang X, Jin F, Wang L. Probiotic and anti-inflammatory attributes of an 
isolate Lactobacillus helveticus NS8 from Mongolian fermented koumiss. BMC Microbiol. 2015; 15:196. doi: 10.1186/s12866-015-0525-2.

89. Lee HA, Kim H, Lee KW, Park KY. Dead Lactobacillus plantarum Stimulates and Skews Immune Responses toward T helper 1 and 17 Polarizations in RAW 264.7 Cells and Mouse Splenocytes. J Microbiol Biotechnol. 2016; 26:469-76. doi: 10.4014/jmb.1511.11001.

90. Quinteiro-Filho WM, Brisbin JT, Hodgins DC, Sharif S. Lactobacillus and Lactobacillus cell-free culture supernatants modulate chicken macrophage activities. Res Vet Sci. 2015; 103:170-5. doi: 10.1016/j.rvsc.2015.10.005.

91. Mortaz E, Adcock IM, Ricciardolo FL, Varahram M, Jamaati H, Velayati AA, Folkerts G, Garssen J. AntiInflammatory Effects of Lactobacillus Rahmnosus and Bifidobacterium Breve on Cigarette Smoke Activated Human Macrophages. PLoS One. 2015; 10:e0136455. doi: 10.1371/journal.pone.0136455.

92. Trasino SE, Dawson HD, Urban JF Jr, Wang TT, SolanoAguilar G. Feeding probiotic Lactobacillus paracasei to Ossabaw pigs on a high-fat diet prevents cholesteryl-ester accumulation and LPS modulation of the Liver $\mathrm{X}$ receptor and inflammatory axis in alveolar macrophages. J Nutr Biochem. 2013; 24:1931-9. doi: 10.1016/j.jnutbio.2013.06.001.

93. Fuentes MC, Lajo T, Carrion JM, Cune J. Cholesterollowering efficacy of Lactobacillus plantarum CECT 7527, 7528 and 7529 in hypercholesterolaemic adults. Br J Nutr. 2013; 109:1866-72. doi: 10.1017/S000711451200373X.

94. Terahara M, Nishide S, Kaneko T. Preventive effect of lactobacillus delbrueckii subsp. bulgaricus on the oxidation of LDL. Biosci Biotechnol Biochem. 2000; 64:1868-73. doi: 10.1271/bbb.64.1868.

95. Valimaki IA, Vuorimaa T, Ahotupa M, Kekkonen R, Korpela R, Vasankari T. Decreased training volume and increased carbohydrate intake increases oxidized LDL levels. Int J Sports Med. 2012; 33:291-6. doi: 10.1055/s0031-1291223.

96. Mikelsaar M, Stsepetova J, Hutt P, Kolk H, Sepp E, Loivukene K, Zilmer K, Zilmer M. Intestinal Lactobacillus sp. is associated with some cellular and metabolic characteristics of blood in elderly people. Anaerobe. 2010; 16:240-6. doi: 10.1016/j.anaerobe.2010.03.001.

97. Yoon HS, Ju JH, Lee JE, Park HJ, Lee JM, Shin HK, Holzapfel W, Park KY, Do MS. The probiotic Lactobacillus rhamnosus BFE5264 and Lactobacillus plantarum NR74 promote cholesterol efflux and suppress inflammation in THP-1 cells. J Sci Food Agric. 2013; 93:781-7. doi: 10.1002/ jsfa.5797.

98. Konieczna P, Schiavi E, Ziegler M, Groeger D, Healy S, Grant R, O’Mahony L. Human dendritic cell DC-SIGN and TLR-2 mediate complementary immune regulatory activities in response to Lactobacillus rhamnosus JB-1. PLoS One. 2015; 10:e0120261. doi: 10.1371/journal.pone.0120261.
99. Elawadli I, Brisbin JT, Mallard BA, Griffiths MW, Corredig M, Sharif S. Differential effects of lactobacilli on activation and maturation of mouse dendritic cells. Benef Microbes. 2014; 5:323-34. doi: 10.3920/BM2013.0066.

100. Ogita T, Bergamo P, Maurano F, D'Arienzo R, Mazzarella G, Bozzella G, Luongo D, Sashihara T, Suzuki T, Tanabe S, Rossi M. Modulatory activity of Lactobacillus rhamnosus OLL2838 in a mouse model of intestinal immunopathology. Immunobiology. 2015; 220:701-10. doi: 10.1016/j.imbio.2015.01.004.

101. Amar Y, Rizzello V, Cavaliere R, Campana S, De Pasquale C, Barberi C, Oliveri D, Pezzino G, Costa G, Meddah AT, Ferlazzo G, Bonaccorsi I. Divergent signaling pathways regulate IL-12 production induced by different species of Lactobacilli in human dendritic cells. Immunol Lett. 2015; 166:6-12. doi: 10.1016/j.imlet.2015.05.001.

102. Zagato E, Mileti E, Massimiliano L, Fasano F, Budelli A, Penna G, Rescigno M. Lactobacillus paracasei CBA L74 metabolic products and fermented milk for infant formula have anti-inflammatory activity on dendritic cells in vitro and protective effects against colitis and an enteric pathogen in vivo. PLoS One. 2014; 9: e87615. doi: 10.1371/journal. pone. 0087615 .

103. Chiba E, Tomosada Y, Vizoso-Pinto MG, Salva S, Takahashi T, Tsukida K, Kitazawa H, Alvarez S, Villena J. Immunobiotic Lactobacillus rhamnosus improves resistance of infant mice against respiratory syncytial virus infection. Int Immunopharmacol. 2013; 17:373-82. doi: 10.1016/j. intimp.2013.06.024.

104. Mariman R, Kremer B, Koning F, Nagelkerken L. The probiotic mixture VSL\#3 mediates both pro- and antiinflammatory responses in bone marrow-derived dendritic cells from C57BL/6 and BALB/c mice. Br J Nutr. 2014; 112:1088-97. doi: 10.1017/S000711451400169X.

105. Christensen HR, Frokiaer H, Pestka JJ. Lactobacilli differentially modulate expression of cytokines and maturation surface markers in murine dendritic cells. J Immunol. 2002; 168:171-8.

106. Saliganti V, Kapila R, Sharma R, Kapila S. Feeding probiotic Lactobacillus rhamnosus (MTCC 5897) fermented milk to suckling mothers alleviates ovalbumin-induced allergic sensitisation in mice offspring. Br J Nutr. 2015; 114:1168-79. doi: 10.1017/S000711451500286X.

107. Kim H, Kim HR, Kim NR, Jeong BJ, Lee JS, Jang S, Chung DK. Oral administration of Lactobacillus plantarum lysates attenuates the development of atopic dermatitis lesions in mouse models. J Microbiol. 2015; 53:47-52. doi: 10.1007/ s12275-015-4483-z.

108. Sakai F, Hosoya T, Ono-Ohmachi A, Ukibe K, Ogawa A, Moriya T, Kadooka Y, Shiozaki T, Nakagawa H, Nakayama Y, Miyazaki T. Lactobacillus gasseri SBT2055 induces TGF-beta expression in dendritic cells and activates TLR2 signal to produce IgA in the small intestine. PLoS One. 2014; 9:e105370. doi: 10.1371/journal.pone.0105370. 
109. Suda Y, Villena J, Takahashi Y, Hosoya S, Tomosada Y, Tsukida K, Shimazu T, Aso H, Tohno M, Ishida M, Makino S, Ikegami S, Kitazawa H. Immunobiotic Lactobacillus jensenii as immune-health promoting factor to improve growth performance and productivity in post-weaning pigs. BMC Immunol. 2014; 15:24. doi: 10.1186/1471-2172-15-24.
110. Bermudez-Brito M, Munoz-Quezada S, Gomez-Llorente C, Romero F, Gil A. Lactobacillus rhamnosus and its cell-free culture supernatant differentially modulate inflammatory biomarkers in Escherichia coli-challenged human dendritic cells. Br J Nutr. 2014; 111:1727-37. doi: 10.1017/ S0007114513004303. 